Forum nie była przypadkowa. Tworzyły ja przede wszystkim: Collegium Polonicum w Słubicach (Studium Filologii Polskiej), Uniwersytet im. Adama Mickiewicza w Poznaniu (Instytut Filologii Polskiej, Katedra Filologii Słowiańskiej, Instytut Nauk Politycznych i Dziennikarstwa), Europejski Uniwersytet Viadrina we Frankfurcie n/Odra (Wydział Nauk o Kulturze), Instytut Serbohużycki w Budziszynie. W Forum uczestniczyły również delegacje Uniwersytetu Christiana Albrechta w Kilonii (Instytut Slawistyki) oraz Akademii Pedagogicznej w Krakowie (Instytut Neofilologii). Po raz pierwszy w spotkamiu tego typu wzięła też udział reprezentacja pracowników i słuchaczy najmłodszej w województwie lubuskim uczelni - Łużyckiej Wyższej Szkoły Humanistycznej w Żarach.

Tematyka zawarta w nazwie imprezy zakreśliła bardzo precyzyjnie treść wykładów „profesorskich" i referatów studenckich, które mieliśmy możliwość wysłuchać. Oto tytuły niektórych spośród nich: „Serbołużyczanie w przeszłości i dziš”, „Polityka mniejszościowa w Niemczech (na przykładzie Serbołużyczan)”, „Mniejszości narodowe w Unii Europejskiej (rozmieszczenie i regulacje prawne)" czy też „Rola przekładów Biblii w rozwoju języków łużyckich".

Dla chętnych przygotowano ponadto dodatkowe zajęcia. Można było się włączyć w dyskusję panelową na temat „Mniejszości w zjednoczonej Europie i w zglobalizowanym społeczeństwie". Sporym zainteresowaniem cieszył się też kurs podstaw języka dolnołużyckiego. Nie zabrakło „pokarmu” dla ducha. Kwartet Jorgi zaprezentował pieśni i melodie łużyckie oraz muzykę innych narodów słowiańskich. Wystąpił również poeta i pieśniarz łużycki Berndt „Pytko” Pittkunings.

Same referaty, dyskusje i kursy nie są oczywiście jedynym powodem, dla którego organizuje się spotkania takie, jak stubickie Forum. Wartość tej imprezy polegała przede wszystkim na żywym kontakcie $\mathrm{z}$ ludźmi reprezentującymi inne środowiska, inne punkty widzenia, inne metody pracy. Spotkanie pozwoliło zaobserwować, ,jak to się robi"... w Poznaniu, Kilonii czy Krakowie. Jest to szczególnie ważne dla studentów młodszych uczelni, które dopiero kształtują swój wizerunek. Powinni oni mieć wiele okazji do zapoznania się z doświadczeniami studentów innych szkół, do nawiązania kontaktów, do dyskusji, do porównań. $Z$ takich spotkań rodzi się potrzeba zdrowej rywalizacji. Budzą się zainteresowania i ambicje naukowe.

Tomasz Fetzki

\title{
Konferencja w Kamieniu Śląskim
}

W dniach 22-23 czerwca 2006 r. w Centrum Kultury i Nauki Wydziału Teologicznego w Kamieniu Śląskim odbyła się Międzynarodowa Konferencja Naukowa zorganizowana przez Instytut Nauk Pedagogicznych Uniwersytetu Opolskiego pt. „Wkład towarzystw oświatowych w rozwój kultury europejskiej - przeszłość - teraźniejszość - przyszłość".

Spotkanie zostało otwarte przez Dziekana Wydziału Historyczno-Pedagogicznego prof. Stefana Marka Grochalskiego oraz przez Dyrektora Instytutu Nauk Pedagogicznych prof. Zenona Jasińskiego. Obaj profesorowie przywitali serdecznie gości z ośrodków krajowych oraz z zagranicy. 
Obradom w pierwszej cześci plenarnej przewodniczyła prof. Eleonora Sapia-Drewniak. Pierwszy wystapił prof. Krzysztof Jakubiak z Uniwersytetu Bydgoskiego, który przedstawił referat pt. „Geneza, cele i formy działalności polskich organizacji rodzicielskich od końca XIX w. do 1939 roku oraz ich rola w uspołecznianiu edukacji szkolnej". Prof. K.Jakubiak, prezentując genezę stowarzyszeń rodzicielskich, uświadomił odbiorcom, jak ważna to działalność, której zadaniem było reprezentowanie interesów rodzin oraz kontrola całego procesu edukacyjnego dzieci, budzenie szacunku, odpowiedzialności, współpraca domu ze szkoła, prowadzenie działalności oświatowej wśród rodziców (tzw. pedagogizacja rodziców). W referacie zaprezentowane zostały pierwsze organizacje rodzicielskie zarówno zagranica, jak i w Polsce, intensywność ich działań i oddziaływań na szkołę, środowisko. W konkluzji referent stwierdził, że od czasów II Rzeczypospolitej nie spotyka się tak prężnie działających stowarzyszeń rodzicielskich, jakie działały wówczas.

Następny referat ukazujący „Działalność i koncepcje oświatowe Towarzystwa Uniwersytetu Ludowego im. A. Mickiewcza na tle rozwoju polskiej myśli i praktyki oświatowej okresu niewoli narodowej" przedstawił prof. Wiesław Jamrożek z Uniwersytetu im. A. Mickiewicza w Poznaniu. Głównym zadaniem TUL, jak przedstawił autor, była edukacja dorosłych. Podstawową formą i metodą działalności Towarzystwa był wykład. TUL prowadziło też bogatą działalność wydawniczą.

Postać Aleksandra Kamieńskiego, przeżywającą obecnie renesans, przybliżył w swoim wystąpieniu pt. „Stowarzyszenia oświatowe w badaniach i koncepcji teoretycznej Aleksandra Kamińskiego" prof. Józef Półturzycki z Uniwersytetu Warszawskiego.

Kolejny gość, prof. F. A. Marek z Wyższej Szkoły Zarządzania i Administracji w Opolu, jako mieszkaniec terenu, na którym odbywała się konferencja, tj. Kamień Śląski, zaprezentował m.in., w sposób bardzo barwny, historię pałacu, w którym miało miejsce spotkanie konferencyjne.

Prof. Agnieszka Stopińska-Pająk z Uniwersytetu Śląskiego w Katowicach przedstawiła referat pt. „Towarzystwo Przyjaciół Nauk na Śląsku - geneza powstania, formy działalności, wkład w kształtowanie życia umysłowego i kulturalnego Śląska". Autorka uświadomiła słuchaczom nierozerwalną historię TPN z dziejami Polski.

W następnym wystappieniu pt. „Some sociological aspects of social inequality in education in Slovenia" prof. Jana Benzenesek zaprezentowała wnioski z przeprowadzonych badań na temat wpływu rodziny na osiągnięcia dziecka w szkole.

Prof. Roman Tomaszewski z Pomorskiej Akademii Pedagogicznej w Shupsku mówił o trzech wielkich pedagogach, myślicielach, których losy zamykają się w latach 1873-1973, a mianowicie o Wacławie Tokarzu, Januszu Jędrzejewiczu oraz Marianie Kukielu, ukazując ich związek między oświatą a polityką, ich wpływ na działalność towarzystw oświatowych.

Prof. F. A. Marek przedstawił historię Towarzystwa Wiedzy Powszechnej, ukazując jego intensywną działalność, nawiązującą do tradycji Towarzystwa Uniwersytetów Ludowych i Towarzystwa Uniwersytetów Robotniczych.

Po przerwie uczestnicy konferencji wysłuchali wspaniałego koncertu na fortepian i altówkę w wykonaniu Krzysztofa Bilińskiego i Mariana Bilińskiego. Następnie rozpoczęto pracę w sekcjach. 
W sekcji pierwszej pod przewodnictwem prof. R. Tomaszewskiego swoją pracę prezentowała m.in. dr Jolanta Szablicka-Żak z Uniwersytetu Wrocławskiego. Ukazała ona sylwetki działaczy oświatowych w Parlamencie II Rzeczypospolitej. Autorka zaprezentowała tych działaczy, którzy w wielu przypadkach, poprzez różnego rodzaju towarzystwa, angażowali się na polu szeroko rozumianej oświaty. Wspomniała o całej gamie towarzystw działających w środowiskach mniejszości narodowych, wskazała liczbę osób posłów, którzy, będąc nauczycielami, profesorami, reprezentowali interesy oświaty polskiej w II RP.

W sekcji drugiej, której przewodniczył prof. K. Jakubiak, pierwszym referentem był dr Edward Nycz, prezentując oświatową działalność Towarzystwa Regionalnego w budowaniu ,społecznego partnerstwa" w warunkach lokalnych, na przykładzie oświatowej działalności Towarzystwa Ziemi Kozielskiej. Autor wskazał na aspekt „nasycenia” danego terenu instytucjami kulturalno-oświatowymi, które niewątpliwie wpływają na proces rozwoju danego środowiska. Takimi są właśnie stowarzyszenia regionalne.

Danijela Lahel z Uniwersytetu w Mariborze - Slovenia przedstawiła referat pt. „Consulting work with classmasters in the Slovene primary school”. Ukazała ona, jak ogromne znaczenie dla właściwej nauki zawodu ma odpowiedni dobór nauczyciela zawodu.

W kolejnym dniu, 23 czerwca, konferencja miała charakter wyłącznie plenarny. Obrady pod przewodnictwem prof. A. Stopińskiej-Pająk otworzyła swoim wystapieniem prof. E. Sapia-Drewniak. Przedstawiła ona rolę polskiej mniejszości narodowej w krzewieniu polskości na Śląsku Opolskim. Zaprezentowała także formy pracy Polsko-Katolickiego Towarzystwa Szkolnego w kształtowaniu świadomości narodowej mieszkańców Opolszczyzny.

Dr Justyna Gulczyńska z Uniwersytetu im. A. Mickiewicza w Poznaniu ukazała działalność Towarzystwa Czytelni Ludowych w procesie kształtowania tożsamości narodowej mieszkańców Wielkopolski.

Dr Krystyna Nowak-Wolan z Uniwersytetu Opolskiego przedstawiła genezę oraz formy działalności Polskiego Związku Teatrów i Chórów Włościańskich.

Po przerwie obrady rozpoczęła dr Irena Czajkowska z Uniwersytetu Opolskiego, przedstawiając organizację i działalność grupy „Guerilla Girls” - organizacji, której założeniem jest protest przeciwko dyskryminacji kobiet w świecie sztuki. Jak ukazała autorka, grupa ta uderza bezpośrednio w różne środowiska, które podważają udział kobiet w sztuce. Istotnym elementem działalności „Guerilla Girls” jest anonimowość - występują w maskach goryli oraz ubrane na czarno. Starają się odgrywać rolę „,sumienia świata" sztuki. Jedną z podstawowych form działalności „Guerilla Girls” jest plakat.

Prof. Z. Jasiński zaprezentował temat pt. „Czeska i polska Macierz Szkolna na Śląsku Cieszyńskim”. Ukazał Macierz Szkolną z perspektywy międzynarodowej, ogromną różnorodność jej działalności - oświatową, wydawnicza, kolportażowa, obronną, ale również dużą wzajemną niechęć obu Macierzy, będącą efektem historycznych urazów.

Konferencja zakończyła się dyskusją podsumowującą dwudniowe obrady. Organizatorzy, ze względu na międzynarodowy charakter spotkania, zapowiedzieli publikację materiałów w języku angielskim. 